\title{
Isolated severe aortic stenosis in a tricuspid aortic valve in a 8-year-old boy
}

\section{Izolowana ciężka stenoza trójpłatkowej zastawki aortalnej u 8-letniego chłopca}

\author{
Santosh Kumar Sinha, Mukesh Jitendra Jha, Vikas Mishra, Divendu Khanra, Avinash Kumar \\ Singh, Amit Goel, Ramesh Thakur \\ Department of Cardiology, LPS Institute of Cardiology, G.S.V.M. Medical College, Kanpur, India
}

\begin{abstract}
A 8-year-old boy was referred for evaluation of ejection systolic murmur. On examination multiple xanthomas and xanthelesmas were noted. Investigations confirmed familial hypercholesterolemia and severe aortic stenosis in background of tricuspid aortic valve. We report a case of severe aortic stenosis in background of morphologically normal valve, a rare complication of heterozygous familial hypercholesterolaemia.
\end{abstract}

Key words: heterozygous FH, rheumatic, tricuspid aortic valve, xanthomatous lesions

Folia Cardiologica 2017; 12, 4: 375-377

\section{Introduction}

Aortic valve stenosis in a young boy in Indian subcontinent is mostly rheumatic in etiology and predominantly multi-valvular. Maldevelopment and genetic factors are other causes but are extremely rare and associated with other left heart obstructive lesions. Here we report a 8-year-old Indian boy who was referred for evaluation of ejection systolic murmur. It was associated with multiple xanthomatous lesions and an elevated serum low-density lipoprotein cholesterol (LDL-C > 558 mg/dL). On screening of the family members (his mother and sibling), deranged lipid profile was also noted in form of very high cholesterol levels with normal high-density lipoprotein cholesterol (HDL-C) and triglyceride levels so heterozygous familial hypercholesterolaemia $(\mathrm{FH})$ was diagnosed. Aortic valve involvement is rare in heterozygous $\mathrm{FH}$ and is usually associated with bicuspid aortic valve but tricuspid aortic valve may be involved as well and such rapid progression to severe aortic stenosis is rarely seen as in our case.

\section{Case report}

A 8-year-old boy was referred for evaluation of ejection systolic murmur. There is no history of orthopnea, paroxysmal nocturnal dyspnoea, chest pain and syncope. Blood pressure in right upper limb in supine position was 100/68 mm Hg. Pulse was 70/minute, regular, normovolemic, slow rising with delayed peaking with no radio-radial or radio-femoral delay. Apical impulse was heaving. On auscultation, grade IV/VI ejection systolic murmur with delayed peaking over aortic area radiating to both carotids was heard. There were multiple, firm, non-tender xanthomatous swelling measurings $1-3 \mathrm{~cm}$ over extensor aspects of both knee, both elbow, buttocks, interdigital area of right hand and outer canthus of right eye (Figure 1) that progressively increased in size in last 2 years. Laboratory examination revealed very high total cholesterol $(630 \mathrm{mg} / \mathrm{dL}$ ) very low-density lipoprotein cholesterol (VLDL-C $32 \mathrm{mg} / \mathrm{dL}$ ), LDL-C (557 mg/dL) levels, normal triglycerides $(160 \mathrm{mg} / \mathrm{dL}$ ) and HDL-C levels (41 mg/dL).

Address for correspondence: Santosh Kumar Sinha MD, FAESC, Asst. Professor, Department of Cardiology, LPS Institute of Cardiology,

G.S.V.M. Medical College, G.T. Road, Kanpur, Uttar Pradesh 208002, India, e-mail: fionasan@rediffmail.com 


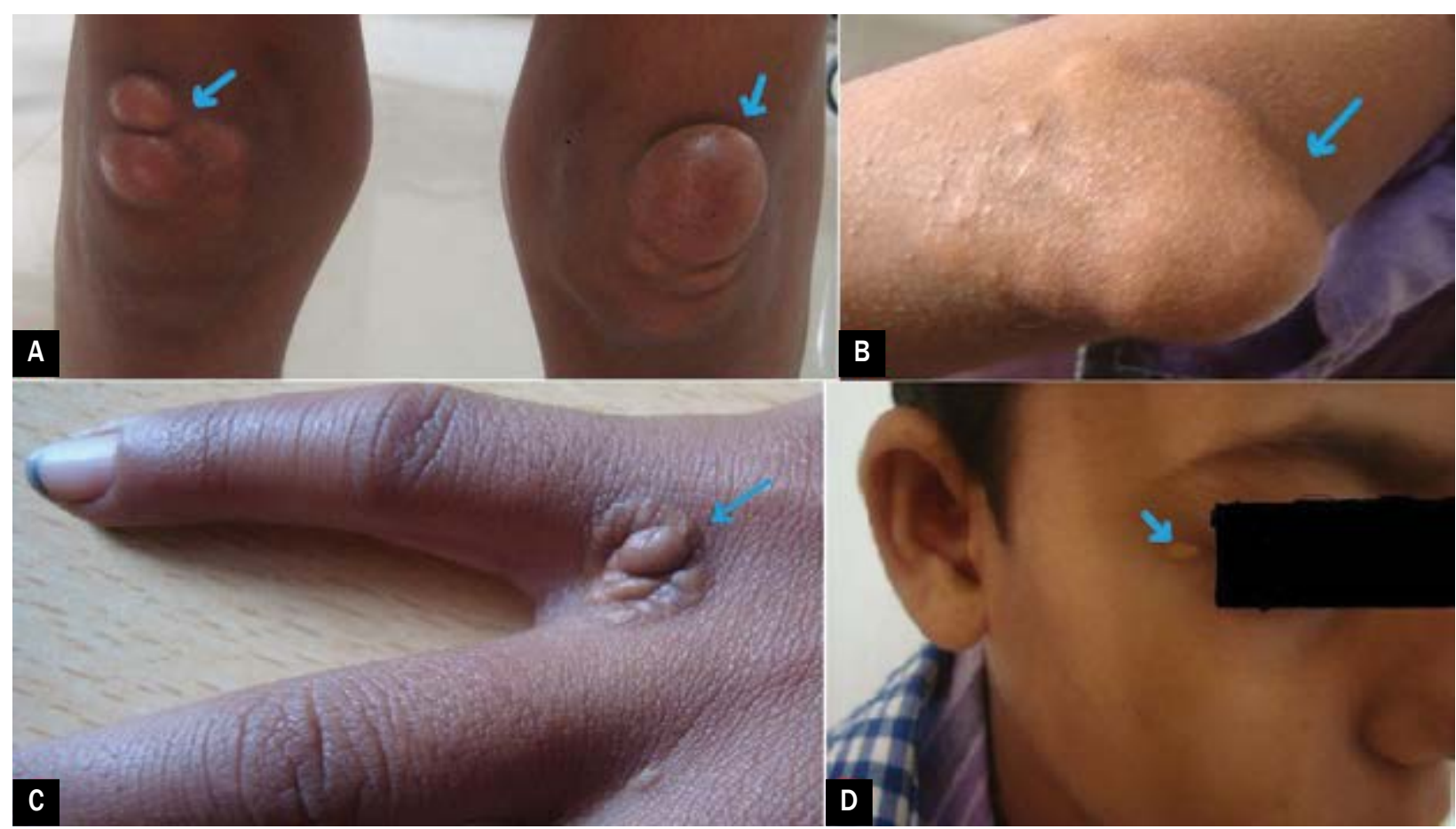

Figure 1A-D. Tuberous xanthomas over extensor surface of both knee joints (A) and elbow joint (B). Plane xanthomas on dorsum of hand in interdigital web space (C) and xantheleshmas on outer canthus (D)

Apolipoprotein B level was high 3.13 (0.56-1.62), with normal apoprotein A level. The screening of other family members revealed very high cholesterol levels with normal HDL-C and triglyceride levels (Figure 2). Thus diagnosis of familial hypercholesterolemia type II A (Fredrickson's classification) was made. His mother, one elder brother and two sister were asymptomatic and without any xanthomas or xantheleshmas. Electrocardiogram shows left ventricular hypertrophy with strain pattern and chest $\mathrm{X}$-ray was normal. 2-D trans-thoracic echocardiography and colour Doppler examination revealed marked concentric left ventricular hypertrophy with severe aortic valve stenosis and normal left ventricular ejection fraction (Figure 3). Fine needle aspiration cytology of swellings revealed fragment of immature adipose tissue and fat cells with large numbers of macrophages. Coronary angiography was done which was normal without atherosclerotic changes. This patient was started on high dose of statins and was planned for AVR.

\section{Discussion}

Homozygous $\mathrm{FH}$ is the most thoroughly studied lipid disorder with incidence of about 1:1,000,000 where incidence of heterozygous $\mathrm{FH}$ is about 1:500 people. The most common cause of death is coronary artery disease (CAD) [1]. Heterozygous FH was diagnosed by primary hypercholesterolemia, skin xanthoma and xantheleshmas. In heterozygote $\mathrm{FH}$, aortic valve involvement is rare and

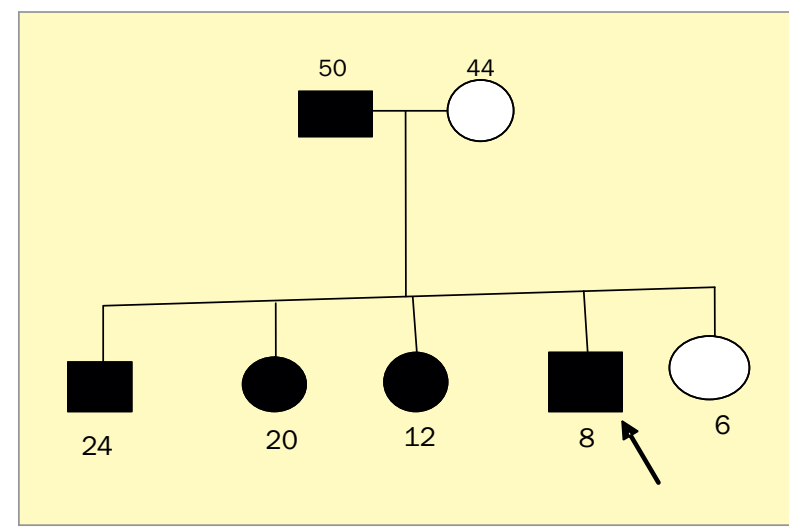

Figure 2. Family pedigree of the patient (arrow). Closed circle and square indicate heterozygous familial hypercholesterolaemia. Arrow represents xanthoma and xantheleshma. Numbers around boxes mean age

occur only with severe and prolonged hypercholesterolemia compared to Homozygotes FH [2]. Since birth, patients with $\mathrm{FH}$ are exposed to the risk of hypercholesterolemia. This risk factor will remain same all through life of these patients in absence of treatment. Such patients exhibit more advanced atherosclerosis and more severe organic disorders than patients with typical hypercholesterolemia, without a relevant genetic background. Bicuspid aortic valve by creating turbulence predisposes to early appearance 


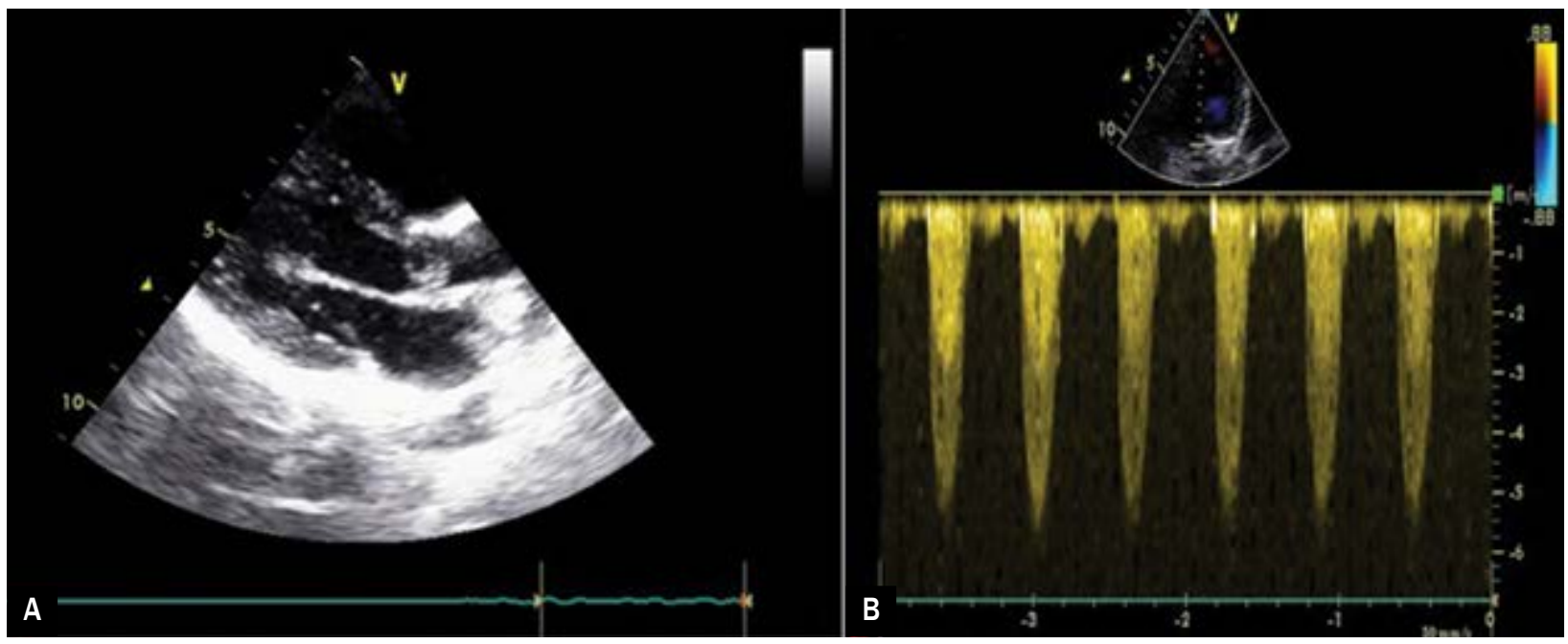

Figure 3A, B. 2D trans-thoracic echo in PLAX view showing thickened aortic valve and mild concentric left ventricular hypertrophy (A) and continuous wave colour Doppler showing severe aortic stenosis (B)

of stenosis as prolonged levels of very high cholesterol in such patients also contributes to early development of aortic stenosis. Severe aortic stenosis though reported in hetero $\mathrm{FH}$, additional risk factors like hypertension, diabetes mellitus, and/or smoking is also present which aggravates aortic valvular dysfunction [3]. The most common cause of aortic stenosis is degenerative though congenital and genetic are commoner at younger age [4]. In Indian sub- continent, rheumatic etiology is commoner than western population. This case is unique as valve was tricuspid and was associated with heterozygous $\mathrm{FH}$ and severe stenosis appeared in first decade.

\section{Conflict of interest(s)}

Authors declared no conflict of interest(s).

\section{Streszczenie}

Ośmioletni chłopiec został skierowany do ośrodka w celu oceny skurczowego szmeru typu wyrzutowego. W badaniu przedmiotowym stwierdzono liczne kępki żółte i kępki żółte płaskie. Na podstawie przeprowadzonych badań rozpoznano hipercholesterolemię rodzinną (FH) i ciężką stenozę zastawki aortalnej o budowie trójpłatkowej. Autorzy opisują przypadek ciężkiej stenozy aortalnej u pacjenta z prawidłową morfologicznie zastawką aortalną, co jest rzadkim powikłaniem heterozygotycznej postaci FH.

Słowa kluczowe: heterozygotyczna FH, choroby reumatyczne, trójpłatkowa zastawka aortalna, kępki zoółte

Folia Cardiologica 2017; 12, 4: 375-377

\section{References}

1. Mortality in treated heterozygous familial hypercholesterolaemia: implications for clinical management. Scientific Steering Committee on behalf of the Simon Broome Register Group. Atherosclerosis. 1999; 142(1): 105-112, doi: 10.1016/s0021-9150(98)00200-7, indexed in Pubmed: 9920511.

2. Neil HA, Hammond T, Huxley R, et al. Extent of underdiagnosis of familial hypercholesterolaemia in routine practice: prospective registry study. BMJ. 2000; 321(7254): 148, indexed in Pubmed: 10894692.
3. Kawaguchi A, Yutani C, Yamamoto A. Hypercholesterolemic valvulopathy: an aspect of malignant atherosclerosis. Ther Apher Dial. 2003; 7(4): 439-443, indexed in Pubmed: 12887729.

4. Weyman AE. Exploring the relationship between hyperlipidemia and aortic stenosis. Rev Cardiovasc Med. 2002; 3(3): 160-161, indexed in Pubmed: 12439442. 